J䟢ALL JOALL (JOURNAL OF APPLIEI) LINGUISTICS ANI) LITERA'TURE)

Vol. 7 No. 1, February 2022

ISSN (print): 2502-7816; ISSN (online): 2503-524X

Available online at https:/ / ejournal.unib.ac.id/index.php/joall/article/view/16516

https://doi.org/10.33369/joall.v7i1.16516

\title{
Overcoming the problem of cultural untranslatability in Burnett's the secret garden from English into Indonesian
}

\author{
${ }^{1}$ Nadia Khumairo Ma'shumah ${ }^{\text {iD, }}$ 'Sajarwa \\ ${ }^{1}$ Graduate School of Linguistics, Universitas Gadjah Mada, INDONESIA \\ 1Jl. Nusantara 1, Bulaksumur Yogyakarta 55281, Indonesia \\ ${ }^{2}$ Associate Professor in Linguistics, Universitas Gadjah Mada, INDONESIA \\ 2Jl. Nusantara 1, Bulaksumur Yogyakarta 55281, Indonesia
}

\begin{tabular}{|c|c|}
\hline ARTICLE INFO & ABSTRACT \\
\hline $\begin{array}{l}\text { Article history: } \\
\text { Received: June 29, } 2021 \\
\text { Revised: Sept 27, } 2021 \\
\text { Accepted: Oct 05, } 2021\end{array}$ & \multirow{5}{*}{$\begin{array}{l}\text { This study aimed at investigating the untranslatable cultural } \\
\text { terms found in the novel from English into Indonesian since } \\
\text { not all cultural terms in Source Text can be fully transferred } \\
\text { into Target Text as well as the translator's decision to overcome } \\
\text { the problem of untranslatability since English and Indonesian } \\
\text { have very different cultural concepts. This study was a data- } \\
\text { driven study by using The Secret Garden's novel written by } \\
\text { Burnett (1911/2019) as the Source Text (ST) and its Indonesian } \\
\text { translation by Kusumawardani (2020) (under the same title) as } \\
\text { the Target Text (TT). The data were analyzed by using } \\
\text { descriptive-mix-comparative methods that combined the } \\
\text { theory of Newmark's (1988) cultural terms categorization and } \\
\text { Newmark's (1988) translation procedures. As a result, to } \\
\text { overcome the problem of cultural untranslatability, the } \\
\text { translator frequently employs transference, naturalization, } \\
\text { and notes procedures. From in-depth analysis, transference by } \\
\text { retaining the SL's cultures in the TL is used to avoid } \\
\text { mistranslation because the lacks a formally corresponding } \\
\text { feature. Naturalization is used by adapting the SL cultural- } \\
\text { specific words to the TL's normal pronunciation and } \\
\text { morphology because there are designation similarities in both } \\
\text { the SL and the TL. Meanwhile, notes in the form of in-text } \\
\text { annotations and footnotes were used to strengthen the } \\
\text { translator's role by highlighting her in the translation results. } \\
\text { Nevertheless, notes are commonly used in conjunction with } \\
\text { naturalization to reduce strangeness, as leaving too many } \\
\text { untranslatable cultural references weakens the translation } \\
\text { result. }\end{array}$} \\
\hline $\begin{array}{l}\text { Keywords: } \\
\text { Cultural terms } \\
\text { Cultural untranslatability } \\
\text { Translation procedures }\end{array}$ & \\
\hline $\begin{array}{l}\text { Conflict of interest: } \\
\text { None }\end{array}$ & \\
\hline $\begin{array}{l}\text { Funding information: } \\
\text { None }\end{array}$ & \\
\hline $\begin{array}{l}\text { Correspondence: } \\
\text { Nadia Khumairo Ma'shumah, } \\
\text { Graduate School of Linguistics, } \\
\text { Universitas Gadjah Mada, } \\
\text { INDONESIA. } \\
\text { nadia.khumairo@mail.ugm.ac.id }\end{array}$ & \\
\hline
\end{tabular}

CNadia Khumairo Ma'shumah \& Sajarwa

This is an open access article under the CC BY-SA 4.0 international license.

\section{How to cite (APA Style):}

Ma'shumah, N.K., \& Sajarwa. (2022). Overcoming the problem of untranslatability in Burnett's the secret garden from English into Indonesian. JOALL (Journal of Applied Linguistics and Literature), 7(1), 34-50. https://doi.org/10.33369/joall.v7i1.16516 
Overcoming the problem of cultural untranslatability in Burnett's the secret garden from...

The problems of language disparities between the source language and the target language challenge the translator's proficiency to overcome such barriers by transferring the cultural terms in appropriate meanings since every language has its own culture (Ariyaratne \& Gunathilaka, 2019; Baker, 2018; Cragie \& Pattison, 2017; Ukpong, 2017; Newmark, 1988). The evidence that translating is not merely a process of language transfer but also involves a transfer from one culture to another then impacted in the difficulty of finding the closest equivalent (Culler, 1976; Rosita, 2017). For this reason, translators are always possessed in a dilemmatic position when dealing with such predicaments as there are no two languages that are sufficiently similar to represent the same social reality (Sapir, 1949). The world in which different societies exist is a distinct world which means that language is bound up with culture in complex ways. Furthermore, no language can exist unless it is immersed in a cultural context, and no culture can exist unless it has the structure of natural language as its center (Sapir and Whorf in Bassnett, 2002), implying that language and culture cannot be separated because it expresses cultural reality. As a consequence, cultural terms are co-constructed and transformed through language.

As the presence of culture has a significant impact on language, translation contributes to the formation of foreign and domestic cultures by respecting cultural differences in cross-cultural communication. Since cultural identity is becoming increasingly important in the translation process, some experts such as Newmark (1988) and Grit (1997) in Diaz-Cintas \& Remael (2014), have proposed some ways to detect and identify specificcultural identity. When Grit (1997) in Diaz-Cintas \& Remael (2014) classified cultural-bound terms into geographical references, ethnographical references, and socio-political references; Newmark (1988), as the former, formulated cultural terms by adapting Nida's theory which consists of ecology; material culture (artifacts), social culture; organizations, customs, activities, procedures; as well as gestures and habits; were useful when dealing with cultural terms identification. However, culture is heterogeneous. Due to the lack of SL culture in the TL culture, the translation of cultural terms became complicated and the issue of "untranslatability" arose (Ariyaratne \& Gunathilaka, 2019). This situation is difficult and forces translators to find appropriate solutions to produce acceptable translations.

Relying on Catford (1965) who states that "untranslatability occurs when it is impossible to incorporate functionally relevant features of the situation into the contextual meaning of the target language text", an audience design (by determining or designing who the prospective readers of the translation are and what is the purpose of translating the text in question), the selection of methods and techniques, appropriate decision making (by involving 
intelligence, sensitivity, intuition)) and translator's general knowledge is needed during the process of translation (Hoed in Machali, 2009). In this case, Baker (2018) declared firmly that the most possible that can be done to deal with untranslatable cultural terms is to suggest some strategies to reach equivalence in some contexts. Because of that, the outcome of the translation process, particularly when dealing with untranslatable cultural terms, is always centered on the translator's role, how the translators adapt or modify the translation, although there is no single translation that is considered to be "the only correct or best translation." (Nord, 2015). Hence, the translation procedures were taken into account as the process of translation is directly involved in the form of interaction and inter-cultural confrontation (Bachmann \& Medick, 1977; Bassnett, 2002; Sajarwa, 2017; Saule \& Aisulu, 2014). Therefore, this problem becomes interesting to investigate from the standpoint of translation.

Some pieces of literature have been carried out relating to the problems of untranslatability in translation. From the intercultural perspective, Wang \& Sunihan (2014) investigate the untranslatability of English and Chinese. They conclude that proper translation strategies reduce the possibility of meaning loss during translation and convert untranslatability into translatability. In another context, Pahlavani et al. (2014) investigate the translatability and untranslatability of collocations in Ernest Hemingway's novels. They suggest that literal translation and functional equivalence are the most frequent strategy used by translators. Moreover, differently, Susanti \& Novalinda (2017) who conducted a study about the problem of untranslatability in the translation of Harry Potter and the Sorcerer's Stone's novel by using Chesterman's (2012) theory discovered that the translator tends to use the loan word or loan word plus explanation strategy to deal with the problem of untranslatability.

All of the underlying studies have concluded that the term "untranslatability" in this context does not imply that it cannot be translated. The most essential point is that they all have been suggested for using translation strategies to overcome the problem of untranslatability as their ultimate conclusion. From the theories and research results mentioned, this study was emphasizing the importance of translation from existing (English) source text into Indonesian and was investigating the translator's decisions as the solution to cope with the problem of cultural untranslatability. Departing from the afore-mentioned studies, this study is still testing whether certain strategies are effective in overcoming the problem of untranslatability by focusing on culture. Unlike previous studies, Newmark (1988) proposed translation procedures were used and tested in this study as an instrument to examine translator decisions. As cultural terms significantly appear and become essential in literary works such as novels, this research focused on the 
Overcoming the problem of cultural untranslatability in Burnett's the secret garden from...

issue of cultural untranslatability in the translation of Burnett's The Secret Garden from English into Indonesian.

The Secret Garden was written by Frances Hodgson Burnett (a British novelist and playwright) in 1910. It was published as a novel in 1911 and is regarded as one of the most popular works of children's literature of all time (see www.amazon.com). Through her masterpiece, Burnett tells the story of a girl named Mary Lennox who was born to a wealthy British family in India. Ironically, her parents sent them to an Ayah to bring her far away. Nevertheless, she relocates from India to Misselthwaite Manor to live with a new family soon after a cholera disease kills her Ayah and all her servants. After living from one place to another place, Mary's adventure story begins when she found a key to the strangest house. With the help of Robin and her friends, she gained access to a secret garden with many plants and friendly animals.

Given that Burnett's The Secret Garden had two distinct settings (India and Misselthwaite Manor (Yorkshire)), cultural diversities in the novel and its translation were examined from both cultural and translation perspectives: This study aimed at investigating (1) the untranslatable cultural terms found in the translation of Burnett's The Secret Garden from English into Indonesian; as well as (2) the translator's decision to overcome cultural untranslatability. This study is expected to shed new light on translation research by establishing a link between language and culture.

\section{METHOD}

\section{Data sources}

The translation of foreign books into Indonesian has revealed the progress of the Indonesian book publishing industries. The free flow of information allows for the exchange of information, knowledge, and culture in global relations. As a result of the widespread translation of textbooks and other semi-literary materials, a type of 'translationese' has emerged in many parts of the world (Nida \& Taber, 1982), and research into it has spread globally.

Following the trend, this study used English literary work since British publishers own a large international market share (Clark \& Phillips, 2019). This study used a canon English novel entitled The Secret Garden written by Francess Hodgson Burnett (1911) (consisting of 27 chapters with 343 pages) published in 2019 (second print) by PT. Gramedia Pustaka Utama as the Source Text and its Indonesian translation under the same title by Airien Kusumawardani (consisting of 27 chapters with 312 pages) published in 2020 by PT. Elex Media Komputindo as the Target Text. The selection of the novel and its translated version as data sources were based on two main reasons. First, The Secret Garden written by Burnett is a kind of fiction and children's literature novel containing many distinctive word choices. Using the setting 
of India and Yorkshire, London; makes The Secret Garden rich in cultural terms. So that, the involvement of several different cultures, makes The Secret Garden is challenging to be translated into Indonesian. Secondly, in regards to the translator competencies, Airien Kusumawardani has been a translator since 2010, specializing in fiction books. She has authored several translated fiction books that have been published by well-known Indonesian publishers. In this case, the translator's background and knowledge are thought to influence the word choices produced in the translated text. (Baker, 2018).

\section{Data collection techniques}

This research employed observation and documentation techniques, as well as a content analysis method focusing on words and phrases containing cultural terms and their Indonesian translations. More than just a counting process, content analysis was chosen to connect the analysis's findings to the context of the discourse or the environment in which they were created. Besides, it also offers a systematic and objective method for drawing valid conclusions from verbal and written data. (Downe-Wambolt in Bengtsson, 2016).

The overall data in this study were taken and collected by applying some steps, such as (1) reading all chapters and pages thoroughly; (2) comparing and contrasting the Source Text (ST) and the Target text (TT) by using comparative method; (3) taking some notes using note-taking method; (4) classifying the data based on cultural terms classifications (Newmark, 1988); (5) reducing the data and specifying the data on cultural untranslatability terms; (6) looking up and double-checking the definitions of each cultural term on Oxford Learner's Dictionary (see www.oxfordlearnersdictionaries.com), KBBI (Kamus Besar Bahasa Indonesia) online (see https://kbbi.kemdikbud.go.id/) and other relevant and credible websites; (8) segregating the data based on translation procedures proposed by Newmark (1988) and formulating the procedures which be used by the translator to deal with the problems of cultural untranslatability; (9) encoding the data into the data sheets; and last (10) counting the occurrences and frequencies of the data by using descriptive statistics.

\section{Data analysis procedures}

This study was data-driven research. It means that the data were interpreted based on the emerging data. This study applied quantitative and qualitative (mixed) data to explore and obtain a depth of understanding (Teddlie \& Tashakkori, 2003). This study analyzed data using several steps, including (1) "Padan Translational" methods conducted by Sudaryanto (1993) and Mastoyo (2007) with the Indonesian language as a determining element; (2) descriptive 
Overcoming the problem of cultural untranslatability in Burnett's the secret garden from...

methods to describe the findings in ST and TT; (3) comparative methods to compare the findings in ST and TT; and (4) interpretative methods to reveal the purpose and facts contained based on the research objectives by checking the acceptability using semantic feature analysis.

\section{Data validation}

To achieve credibility, dependability, transferability, and conformability in this study, triangulation techniques were employed by utilizing something outside the data to verify the data findings (Moleong, 2001) and also to make the data more accurate by using different methods and techniques (Denzin, 1970). This study applied theoretical triangulation and methodological triangulation. Theoretical triangulation was conducted by implying multiple theories from books, papers, journals, and the internet in analyzing and interpreting the data. Methodological triangulation was carried out by combining qualitative and quantitative research in the form of numbers, as well as their interpretation based on the results. In this study, triangulation tends to complement each other.

\section{FINDINGS}

These findings showed the problems of cultural untranslatability (CU) found in the translation of Burnett's The Secret Garden into Indonesian as well as the translation procedures for overcoming cultural untranslatability.

The untranslatability of cultural terms categorization in the translation of Burnett's the secret garden into Indonesian

From the depth analysis, the results showed that there were 4 types of untranslatable cultural terms and 9 categories found in the translation of Burnett's The Secret Garden into Indonesian. The results were presented qualitatively in Table 1.

Table 1. Percentages of untranslatable cultural terms and their categories found in the novel

\begin{tabular}{|c|c|c|c|}
\hline Numb. & $\begin{array}{c}\text { Cultural } \\
\text { Types }\end{array}$ & Categories & $\begin{array}{c}\text { Occurrences } \\
\text { and } \\
\text { Frequencies }\end{array}$ \\
\hline 1. & Ecology & $\begin{array}{l}\text { Flora } \\
\text { Silver Bell, Cockle Shell, Marigold, Heather, } \\
\text { Gorse, Broom, Blackberry, Heather-Bell, Collie, } \\
\text { Crocus, Snowdrop, Daffodil, Jonquil, Narcissus, } \\
\text { Purple Flag, Laurel, Larkspur, Mignonette, } \\
\text { Holly, Poppy, Daffydowndilly, Lilies of The } \\
\text { Valley, Canterbury, Iris, Primrose, Aquilegia, } \\
\text { Columbine, Shrubbery, Lilac, Rhododendron, } \\
\text { Delphinium, Campanula, Pink, Pansy, }\end{array}$ & $109(15.03 \%)$ \\
\hline
\end{tabular}




\begin{tabular}{|c|c|c|c|}
\hline Numb. & $\begin{array}{l}\text { Cultural } \\
\text { Types }\end{array}$ & Categories & $\begin{array}{c}\text { Occurrences } \\
\text { and } \\
\text { Frequencies }\end{array}$ \\
\hline & & $\begin{array}{l}\text { Foxglove, Rock-Cress, Hedgerow, Currant, } \\
\text { Forget-Me-Not }\end{array}$ & \\
\hline & & $\begin{array}{l}\text { Fauna } \\
\text { Skylark, Robin, Missel }\end{array}$ & $164(22.62 \%)$ \\
\hline \multirow[t]{4}{*}{2.} & $\begin{array}{l}\text { Material } \\
\text { Culture }\end{array}$ & $\begin{array}{l}\text { Food(-s) } \\
\text { muffin, crumpet }\end{array}$ & $4(0.55 \%)$ \\
\hline & & $\begin{array}{l}\text { Place(-s) } \\
\text { bungalow, fyord }\end{array}$ & $9(1.24 \%)$ \\
\hline & & $\begin{array}{l}\text { Cloth(-es) } \\
\text { stocking, bonnet }\end{array}$ & $6(0.83 \%)$ \\
\hline & & $\begin{array}{l}\text { Currency(-ies) } \\
\text { shilling, penny, pence, sovereign, crown }\end{array}$ & $15(2.07 \%)$ \\
\hline \multirow[t]{2}{*}{3.} & Social Culture & $\begin{array}{l}\text { Song(s) } \\
\text { Riquet à la Houppe, Mary Quite Contrary }\end{array}$ & $2(0.28 \%)$ \\
\hline & & $\begin{array}{l}\text { Social Status(-es) } \\
\text { Ayah, Mem Sahib, Missie Sahib, Sahib, Mester, } \\
\text { Colonel, Captain, Ma'am, Sir, dr., Mr., Mrs., } \\
\text { Miss }\end{array}$ & $411(56.69 \%)$ \\
\hline \multirow[t]{2}{*}{4.} & $\begin{array}{l}\text { Social } \\
\text { Organization, } \\
\text { Political and } \\
\text { Administrative }\end{array}$ & $\begin{array}{l}\text { Religious term(-s) } \\
\text { Doxology }\end{array}$ & $5(0.69 \%)$ \\
\hline & & TOTAL & $725(100.00 \%)$ \\
\hline
\end{tabular}

Derives from a total of 725 data of cultural untranslatability terms, the most frequent untranslatable cultural term is social culture relating to social status, followed by fauna and flora as part of ecological terms, currencies, places, clothes, foods, religious terms, and songs. By seeing the results, it can be inferred that since every region have their endemics or peculiarities, they belong to cultural-specific items which need special considerations.

Translation procedures as translator's decisions in translating Burnett's the secret garden into Indonesian

This study found that there are three translation procedures used by the translator as translator's decisions to deal with the situation when the target language lacks of equivalent concept and suitable expression in translating Burnett's The Secret Garden into Indonesian. The findings are shown in Table 2 below.

Table 2. Translation procedures used by the translator to overcome cultural untranslatability

\begin{tabular}{clr}
\hline No & \multicolumn{1}{c}{ Translation Procedures } & Occurrences and Frequencies \\
\hline 1. & Transference & $565(77.93 \%)$ \\
\hline 2. & Naturalization & $152(20.97 \%)$
\end{tabular}


Overcoming the problem of cultural untranslatability in Burnett's the secret garden from...

\begin{tabular}{|c|c|c|}
\hline No & Translation Procedures & Occurrences and Frequencies \\
\hline 3. & Notes & $7(0.97 \%)$ \\
\hline 4. & Mistranslation as a translation error & $1(0.14 \%)$ \\
\hline & TOTAL & $725(100.00 \%)$ \\
\hline
\end{tabular}

From the table above, the most frequent translation procedure applied in the translation of Burnett's The Secret Garden from English into Indonesian is transference which occurs 565 times (77.93\%) of the total translation procedures, followed by naturalization which occurs 152 times $(20.97 \%)$ and notes which occurs 7 times $(0.97 \%)$. Through the analysis, it can be seen that there is 1 (a single) data (0.14) that belongs to mistranslation as the efforts made by the translator to achieve equivalence are not always appropriate and suitable to be used in the target language. These findings serve as a reference for concluding the translator's decision to overcome the problem of cultural untranslatability in Burnett's The Secret Garden from English into Indonesian.

\section{DISCUSSION}

The entire collection of the data has been analyzed by exploring cultural untranslatability categorization and translation procedures as translator's decisions in the translation of Burnett's The Secret Garden into Indonesian. Based on the analysis on Burnett's The Secret Garden and its translation into Indonesian as the data, the findings showed that the translator intends to use (1) 'transference' (which is also known as emprunt or loan word or transcription) by directly transferring the SL word to the TL text; (2) 'naturalization' by adapting the SL word to the normal pronunciation and the normal morphology (word-forms) of the TL; and (3) 'notes' by inserting additional information besides the terms and at the bottom of the page. From the findings, notes in the form of in-text annotations and footnotes were applied by the translator.

\section{The translation of specific-social cultures}

To deal with the issue of untranslatability, the translator used some of the strategies proposed by Newmark (1988), as social cultures became the most prominent cultural untranslatability in both texts. The following examples are of untranslatable social culture found in the translation of Burnett's The Secret Garden into Indonesian.

(1) ST: ...when Mary was born, she handed her over to the care of an Ayah. (SG, 1911/2019: 7)

TT: ...ketika Mary lahir, ibunya menyerahkan Mary untuk diurus seorang Ayah'.

${ }^{1}$ Sebutan untuk pengasuh atau pelayan perempuan di India yang berdarah asli India. (SG, 2020: 2) 
In excerpt (1) the translator decided to use notes in the form of footnotes as additional information for the readers since the author or writer tends to use loan words in the source text. Here, the translator indicates that retaining the source cultural term was important. It proves that the translator wants her presence will be visible in her literary work. By the presence of notes for the term "Ayah" in excerpt (1), it became effective in guiding the target readers and ensuring the readers' full understanding of the foreign words that appear in the source text by providing a clear interpretation.

(2) ST: Colonel McGrew said he nearly jumped out of his skin when he opened the door and found her standing by herself in the middle of the room. (SG, 1911/2019: 18)

TT: Kolonel McGrew bilang dia hampir terkejut setengah mati ketika membuka pintu dan menemukan Mary berdiri sendirian di tengah ruangan. (SG, 2020: 13)

Since social class shapes relational realities (Carey \& Markus, 2017), translating cultural terms relating to social stratification becomes difficult and tricky. As a result, the translator must connect the SL's social class to the TL's social class. In excerpt (2), as an example case, the translator tends to use naturalization since the term "kolonel" also can be found in Indonesian terms with the same referent as SL [+man, +army officer high rank].

(3) ST: She had just remembered a French fairy story she had once read called "Riquet à la Houppe". (SG, 1911/2019: 24)

TT: Dia baru saja mengingat cerita dongeng Prancis yang pernah dibacanya berjudul Riquet à la Houppe. (SG, 2020: 18)

"Riquet à la Houppe" or "Ricky with the Tuft" is well-known as a French literary fairy tale. It was written by Charles Perrault as part of his 1697's anthology entitled Histoires ou Contes Du Temps Passé (Fairy Tales from Past Times with Morals or Mother Goose Tales). In this case, the translator in excerpt (3) decided to retain the original title with transferred bodily into TL by the use of loan words in the source text. The translator tends to follow the author's decision because if "Riquet à la Houppe" is translated into Indonesian the nuance of French will be lost. This proves that the translator tends to use translation as a medium to introduce SL cultures to TL readers. (Bachmann \& Medick, 1977; Saule \& Aisulu, 2014).

\section{The translation of specific-ecological terms}

As proposed by Newmark (1988), many countries have 'local' words. Consequently, they will be more or less lexical items in the TL and may be 
Overcoming the problem of cultural untranslatability in Burnett's the secret garden from...

subject to naturalization because they were hard to be translated into the TL. Nonetheless, these findings demonstrated the polar opposite of the previous theory. These findings found that in addition to using naturalization, the translator intensively used transference and notes as procedures in translating The Secret Garden into Indonesian. The excerpts below are examples of untranslatable ecological terms found in the translation of Burnett's The Secret Garden into Indonesian.

(4) ST: Nor it isn't fields nor mountains, it's just miles and miles and miles of wildland that nothing grows on but heather and gorse and broom... (SG, 1911/2019: 30)

TT: Ini juga bukan padang rumput ataupun pegunungan, hanya tanah liar seluas bermil-mil di mana tidak ada apa pun yang tumbuh selain semak berbunga heather ${ }^{3}$, gorse ${ }^{4}$, dan broom $^{5}$.

${ }^{3}$ Semak berbunga ungu-merah muda, sesekali putih, yang termasuk ke dalam tanaman yang berdaun dan berbunga hampir sepanjang tahun dan lebah yang mengisap sarinya dapat menghasilkan madu heather yang bercita rasa kuat dengan tekstur seperti agar-agar.

"Salah satu jenis tanaman yang menghasilkan bunga berwarna kuning, termasuk tanaman hijau abadi yaitu yang selalu berdaun hijau apapun musimnya.

${ }^{5}$ Semak berbunga kuning yang dapat tumbuh hingga sekitar 1-3 meter, bisa tumbuh di tanah kering atau berpasir dan mampu bertahan sampai suhu sekitar -25 derajat Celcius. (SG, 2020: 23)

In excerpt (4), the translator decided to use transference to emphasize the actual setting of the place (which was in the Western context) as footnotes are linked to the cultural burden of a community, such as meals and food, clothes and accessories, beliefs and customs (Herrero, 2005) which can help to promote a better understanding of the source culture (Luo \& Zhang, 2018). Through the use of notes in the form of footnotes in excerpt (4), the translator can fill a gap in the target readers' understanding of the source-language culture.

(5) ST: But the robin seemed to be quite satisfied and chirped and whistled back at her. (SG, 1911/2019: 59)

TT: Tetapi burung robin itu terlihat cukup puas dan dia bercicit serta bersiul membalas Mary. (SG, 2020: 49)

As an endemic species of North American thrush, the Robin is one of the most well-known songbirds in the eastern United States. Cited from www.britannica.com, early colonial settlers named it "robin" because its breast color resembled a smaller thrush. Therefore, based on the analysis of excerpt (5), naturalization was applied by the translator since Indonesian has 
the same reference as English in terms of the Robin. In this case, Indonesian people called "Robin" as "burung Robin" with the same references by retaining its original name.

\section{The translation of specific-material culture}

A plenitude of references to contemporary social institutions and conventions poses challenges to all translators (López, 2018). For this reason, the translation of cultural terms needs to be based on a mastery of information about them. The examples of untranslatable material culture found in the translation of Burnett's The Secret Garden into Indonesian can be seen below.

(6) ST: It was true that there was no one in the bungalow but herself and the little rustling snake. (SG, 1911/2019: 14)

TT: Memang benar, tidak ada seorang pun di bungalo itu kecuali Mary dan si ular kecil yang bergemerisik. (SG, 2020: 9)

Newmark (1988) mentioned that many language communities in the world have a typical and specific house that remains untranslated since it was strongly bounded with national identity. A simple search from the internet showed that the word "bungalow" comes from the Hindi word Bangla in 1676 and according to Oxford Learner's Dictionary, bungalow resembles "a house built all on one level, without stairs". When associated with the Indonesian context, the word "bungalo" is naturalized. Relating to this, KBBI defines bungalo as "rumah peristirahatan di luar kota (di daerah pegunungan atau di pantai), ada yang dibangun secara permanen, ada juga yang tidak". Based on the analysis, naturalization is used by the translator in excerpt (6) because the source language has a designation similarity in the target language.

(7) ST: It was an agreeable idea, easily carried out, and when the white the cloth was spread upon the grass, with hot tea and buttered toast and crumpets... (SG, 1911/2019: 253)

TT: Gagasan itu cukup menyenangkan, mudah dijalankan, dan ketika taplak putih dihamparkan di atas rumput, dengan sajian teh panas, roti panggang dan crumpet beroles mentega,... (SG, 2020: 229)

Food terms are subjected to the most diverse range of translation procedures because they are the most sensitive and important expression of national culture (Newmark, 1988). Because of that, in excerpt (7), "crumpet" cannot be translated into Indonesian because it is not lexicalized in the target language. It means that Indonesian has no reference to "crumpet". Cited from Oxford Learner's Dictionary (see www.oxfordlearnersdictionaries.com), a "crumpet" is defined as a small flat round cake with small holes in the top that is eaten hot with butter. Crumpet is categorized as a traditional British teatime 
Overcoming the problem of cultural untranslatability in Burnett's the secret garden from...

treat that originated in the 17th century which was well-known as thin pancakes made from flour, milk, and egg base. However, today's version, likely developed in the Victorian era, bakers modified crumpets by adding yeast and then baking powder to the recipe (see www.britannica.com). Here, the translator transfers the SL to the TL by using transference procedures in excerpt (8) as there is no suitable word to transfer "crumpet" into the target text.

(8) ST: She wore a very purple dress, a black silk mantle with jet fringe on it and a black bonnet with purple velvet flowers which stuck up and trembled when she moved her head. (SG, 1911/2019: 19)

TT: Dia memakai gaun ungu terang, mantel sutra hitam berhiaskan rumbai hitam gelap, dan topi bonnet hitam dengan bunga-bunga beledu ungu yang mencuat dan bergetar saat dia menggerakkan kepalanya. (SG, 2020: 14)

Newmark (1988) proposed that clothing as a cultural term can be adequately explained for TL readers if the generic name or classifier is added. Bonnet was not fluent in Indonesian. As "bonnet" is strongly associated with British culture and cannot be lexicalized in the target language, the translator used the transference procedure on the excerpt (8). The word "bonnet," defined as "a hat tied with strings under the chin, worn by babies and, particularly in the past, by women," was retained in the target text. Looking back in time, the bonnet was worn by elite women in informal contexts from the eighteenth century. However, since the nineteenth century, bonnet became the dominant and general term used for female hats.

(9) ST: He smiled at their friendly grins and took a golden sovereign from his pocket and gave it to "our 'Lizabeth Ellen" who was the oldest. (SG, 1911/2019: 334)

TT: Lelaki itu tersenyum melihat senyum ramah mereka lalu mengeluarkan koin sovereign ${ }^{14}$ emas dari sakunya dan memberikannya kepada 'Lizabeth Ellen, yang merupakan anak tertua.

${ }^{14 N a m a ~ k o i n ~ e m a s ~ B r i t a n i a ~ R a y a, ~ d e n g a n ~ n i l a i ~ n o m i n a l ~ s a t u ~ p o u n d s t e r l i n g ~ d a n ~}$ sudah berhenti dicetak ketika James I dinobatkan sebagai raja Inggris dan Skotlandia pada tahun 1603. (SG, 2020: 305)

In excerpt (9), "sovereign" as a Great British currency cannot be translated into Indonesian due to its strong connection with national identity along with its history. Besides, currencies are bound by international conventions, so, in the case of excerpt (9), the translator used transference procedures and decided to bring the word "sovereign" into the Indonesian translation. It is given by a footnote to help and guide the readers to connect 
with its meaning in an attempt to serve acceptable translation for the target readers. The footnotes in this case also help to make the reference clear to the readers.

The translation of specific-social organization, political and administrative In religious language, the proselytizing of Christianity's activities is reflected in manifold translation (Newmark, 1988). Therefore, the translators focus on the appropriateness of translating religious languages. The following examples are the examples of untranslatable social organization, political and administrative, found in the translation of Burnett's The Secret Garden into Indonesian.

(10) ST: Tha' might sing th' Doxology. (SG, 1911/2019: 313)

TT: Kau bisa menyanyikan Doksologi ${ }^{10}$.

${ }^{10}$ Himne pendek yang digunakan di berbagai kebaktian Kristen, sering dinyanyikan pada akhir kebaktian. (SG, 2020: 285)

According to Firth in Bassnett (2002), meaning is a complex of various types of relationships between the component concepts of a situational context. Thus, since translating religious terms is very sensitive and complicated, in excerpt (10) the translator chooses to use a footnote to maintain its SL meaning. At a glance, the dictionary defines doxology as an expression of praise to God, particularly a short hymn that was sung as part of a Christian worship service. As doxology is often added at the end of canticles, psalms, and hymns, notwithstanding, the themes expressed in doxologies are scriptural. For its long history, the term "doxology" should not be translated because of its sensitivity.

(11) ST: But Colin was of an exploring mind and he knew nothing about the Doxology. (SG, 1911/2019: 313)

TT: Tetapi pikiran Colin sedang menjelajah dan dia tidak tahu apa pun tentang Doksologi. (SG, 2020: 285)

In contrast to excerpt (10), the translator chooses naturalization in excerpt (11) because the reader is assumed to know or have general knowledge of the meaning of the SL. This was proven by the presence of the note procedure, which was already provided by the translator in the preceding sentence (as in excerpt (10)). According to the analysis, the use of naturalization reduces the strangeness of the source's cultural term by completely avoiding the use of loans or foreign words. 
Overcoming the problem of cultural untranslatability in Burnett's the secret garden from...

Mistranslation in translating culture-specific terms

From the data findings, this study also found mistranslation in the translator's decision.

(12) ST: Mistress Mary, quite contrary, how does your garden grow? with silver bells, cockle shells, and marigolds all in a row. (SG, 1911/2019: 16)

TT: Nona Mary, si pembangkang, bagaimana tamanmu kau tata? dengan bunga silver bell dan cockle shell, dan marigold semuanya berbaris. (SG, 2020: 11)

"Mistress Mary, quite contrary" in excerpt (12) is a verse from Mother Goose's English traditional nursery song that is widely popular with all its controversies. Eventually, the interpretation of the songs was still debatable until now. Nevertheless, although the phrase 'quite contrary' is difficult to translate because it relates to a song, it cannot simply be translated into "si pembangkang" in Indonesian. As a result, translating "quite contrary" into "si pembangkang" was not appropriate because the meaning of "Miss Mary, quite contrary" was still debated by experts due to the conspiracy theory. They believed that the song "Mistress Mary, quite contrary" had religious and historical significance. This discovery proved that rather than using literal translation procedures, transference, naturalization, and notes can be preserved to avoid translation errors or mistranslation.

\section{CONCLUSION}

The problem of untranslatability challenges the translators. Thus, cultural terms found in the data are less translatable since the TL mostly has no formally corresponding feature. When the aforementioned study found that the loan word or loan word plus explanation strategy can be used to deal with the problem of untranslatability (Susanti \& Novalinda, 2017), this study underlined that transference, naturalization, and notes were applied by the translator relying on Newmark's (1988) translation procedures. the research findings also showed that these three translation procedures are quite effective to overcome the problem of cultural untranslatability, such as specific social culture, ecological terms, material culture, and social organization, political and administrative; and to avoid translation errors. The use of notes as one of the translator's decisions tended to make her visible in the TT, whereas the use of transference already demonstrates that the more serious and knowledgeable the readership, the more important transference is, not only in terms of cultural and institutional terms, but also of titles, addresses, and words used in a specific sense (Newmark, 1988). The study's findings concluded that every strategy, procedure, and method offer a 
solution to translation difficulties, one of which is retaining words from the source text into the target text via transference, naturalization, and notes.

Nonetheless, this investigation was limited to the exploration of cultural terms in the novel as well as the issue of untranslatability in the novel's translation. Considering that the problems of untranslatability are very broad due to language differences, the study of untranslatability opens a large field in translation studies along with the development of languages around the world, particularly when it is associated with the dominance of patronage (such as publisher and editor). For the next researchers, it is expected that future researchers will use other material objects and discourses as data, such as film subtitles, surtitles, non-fictional works, speeches, textbooks, and so on when researching the same focus. Furthermore, it was necessary to investigate the impact of transference, naturalization, and notes to the target readers on their accuracy, readability, and acceptability.

\section{ACKNOWLEDGMENTS}

We would like to express our heartfelt appreciation to the editor and/or anonymous reviewers who provided feedback on our piece of writing.

\section{REFERENCES}

Ariyaratne, M., \& Gunathilaka, I. (2019). Overcoming cultural untranslatability: with special reference to Wickramasinghe's "Gamperaliya" and its English translation, "Uprooted" by Lakshmi de Silva and Ranga Wickramasinghe. Volume III, 2454-6186.

Bachmann, D., \& Medick. (1977). Meanings of translation in cultural anthropology. In T. Herman (Ed.), Translating Others (pp. 33-42). ST Jerome Publishing.

Baker, M. (2018). In Other Words: A Coursebook on Translation (3rd ed.). Routledge.

Bassnett, S. (2002). Translation Studies (3rd ed.). Routledge.

Bengtsson, M. (2016). How to plan and perform a qualitative study using content analysis. NursingPlus Open, 2, 8-14. https://doi.org/https://doi.org/10.1016/j.npls.2016.01.001

Burnett, F. H. (2019). The Secret Garden (2nd ed.). Gramedia Pustaka Utama. Burnett, F. H. (2020). The Secret Garden (A. Kusumawardhani, Ed.). PT. Elex Media Komputindo.

Carey, R. M., \& Markus, H. R. (2017). Social class shapes the form and function of relationships and selves. Current Opinion in Psychology, 18, 123-130. https:// doi.org/10.1016/j.copsyc.2017.08.031

Catford, J. (1965). A Linguistic Theory of Translation. Oxford University Press. Clark, G., \& Phillips, A. (2019). Inside Book Publishing. Routledge. 
Overcoming the problem of cultural untranslatability in Burnett's the secret garden from...

Cragie, S., \& Pattison, A. (2017). Thinking Translation: Analyzing and Translating English Source Text. Routledge.

Culler, J. (1976). Structuralist Poetics: Structuralism, Linguistics and the Study of Literature. Routledge.

Denzin, N. (1970). The Research Act in Sociology. Aldine.

Diaz-Cintas, J., \& Remael, A. (2014). Audiovisual Translation, Subtitling (2nd ed.). Routledge.

Herrero, L. (2005). Regional Indian literature in English: translation or recreation? In A. Branchadell \& L. M. West (Eds.), Less Translated Languages (pp. 225-235). John Benjamins.

Landers, C. (2001). Literary Translation: A Practical Guide. Multilingual Matters.

López, I. H. (2018). Translating social and material culture: Sanditon in Spanish. Translation and Literature, 27(1), 53-69. https:/ / doi.org/10.3366/tal.2018.0321

Luo, T., \& Zhang, M. (2018). Reconstructing cultural identity via paratexts: a case study on Lionel Giles' translation of The Art of War. Perspectives, 26(4), 593-611. https:// doi.org/10.1080/0907676X.2017.1401650

Machali, R. (2009). Pedoman Bagi Penerjemah. PT. MIzan Pustaka.

Mastoyo, Y. T. (2007). Pengantar (Metode) Penelitian Bahasa. Carasvatibook.

Moleong, L. Y. (2001). Metode Penelitian Kualitatif. PT. Penerbit Remaja Rosdakarya.

Newmark, P. (1988). A Textbook of Translation. Prentice Hall International vUIO Ltd.

Nida, E. A., \& Taber, C. R. (1982). The Theory and Practice of Translation (2nd ed., Vol. 8). E.J.Brill.

Nord, C. (2015). Translating as a Purposeful Activity: Functionalist Approaches Explained. Routledge.

Pahlavani, S. D., Bateni, B., \& Hosseini, H. S. (2014). Translatability and untranslatability of collocations in Ernest Hemingway's novels. European Online Journal of Natural and Social Sciences, 3(4), 1195-1206.

Rosita, N. (2017). Translation techniques in Taj: tragedi di balik tanda cinta abadi novel. Lingua Didaktika: Jurnal Bahasa Dan Pembelajaran Bahasa, 10(2), 137. https://doi.org/10.24036/ld.v10i2.7239

Sajarwa, S. (2017). Deconstructing equivalence in the translation of texts from French to Indonesian. Jurnal Humaniora, 29(2), 159.

https://doi.org/10.22146/jh.24063

Sapir, E. (1949). Gradation: a study in semantics. In Selected Writings of Edward Sapir in Language, Culture, and Personality. University of California Press.

Saule, B., \& Aisulu, N. (2014). Problems of translation theory and practice: original and translated text equivalence. Procedia - Social and Behavioral 
Sciences, 136, 119-123.

https://doi.org/https://doi.org/10.1016/j.sbspro.2014.05.300

Sudaryanto. (1993). Metode dan Aneka Teknik Analisis Bahasa: Penelitian

Wahana Kebudayaan Secara Linguistis. Duta Wacana University Press.

Susanti, M., \& Novalinda. (2017). Untranslatability found in J.K. Rowling's English novel Harry Potter and The Sorcerer's Stone and its Indonesian version. Vivid: Journal of Language and Literature, 6(2).

Teddlie, C., \& Tashakkori, A. (2003). Major issues and controversies in the use of mixed methods in the social and behavioral sciences. In $\mathrm{C}$.

Teddlie \& A. Tashakkori (Eds.), Handbook of mixed methods in the social and behavioral sciences (pp. 3-50). Thousand Oaks.

Ukpong, D. E. (2017). Social and cultural barriers in translation. Human and Social Studies, 6(1), 77-87. https://doi.org/10.1515/hssr-2017-0006

Wang, J., \& Sunihan, S. (2014). An analysis of untranslatability between English and Chinese from intercultural perspective. English Language Teaching, 7(4). https://doi.org/10.5539/elt.v7n4p119

\section{THE AUTHOR}

Nadia Khumairo Ma'shumah is a graduate school of linguistics student majoring in translation studies at Universitas Gadjah Mada Indonesia, funded by the BPI-LPDP for a domestic scholarship. She is currently active and focused on various translation research to dissect interesting things in linguistics and translation areas, as linguistics and translation are like gold mines that never stop being scrutinized and investigated.

Sajarwa is an associate professor of linguistics at Universitas Gadjah Mada's Graduate School of Linguistics and French study program. As a senior lecturer and academic, he is currently focused on sharing and dedicating his knowledge by teaching linguistics and translation, as well as conducting various researches in those fields of study. 